\title{
Synchronized Quantitative Assessment of Corticosteroid and Bronchodilator in Rotacaps by HPTLC using Fractional Factorial Design
}

\author{
Aarti Sachin Zanwar, ${ }^{1,}$, Dhanya B Sen${ }^{1}$, Charu Paresh Pandya², Avinash Kumar Seth ${ }^{1}$, Rajesh \\ Maheshwari', Ashim Kumar Sen ${ }^{1}$
}

1Department of Pharmacy, Sumandeep Vidyapeeth Deemed to be University, Piparia, Waghodia, Vadodara, Gujarat, INDIA. ${ }^{2}$ Parul Institute of Pharmacy, Parul University P.O. Limba Ta. Waghodia, Vadodara, Gujarat, INDIA.

\begin{abstract}
Background: A validated high performance planar chromatographic analysis for a combination medication of corticosteroids mometasone furoate and bronchodilators formoterol fumarate available as Evocort ${ }^{\circledR}$ : inhaler in market was developed. It is used for treating asthma, a reversible obstructive airways disease. Materials and Methods: The HPTLC chromatographic condition was optimised using aluminium sheets formerly coated with silica gel $60 \mathrm{~F}_{254}$ as stationary phase and toluene: methyl alcohol: methanoic acid $(12.5: 4: 0.3 \mathrm{v} / \mathrm{v} / \mathrm{v})$ as mobile phase. Results: Formoterol fumarate and mometasone furoate concentration was found to be directly proportional to peak area in the range of 120-720 ng/band and 3996-23976 ng/band, respectively. Results of precision studies were between 0.77-1.274 stated in \%RSD and recovery studies ranged from 99$101 \%$ indicating very low inter day variability and good reproducibility of the method. Fractional factor design was applied to five factors i.e. volume of mobile phase, amount of methyl alcohol in mobile phase, chamber saturation time, development distance, time from chromatography to scanning to study its effect on retardation factor and peak area of both the drug. Conclusion: The 3D response surface graphs exposed that ratio of methyl alcohol in the mobile phase was slightly rigorous factors affecting the responses. The compatibility of linearity ranges with ratio in their combined rotacaps and also nonappearance of excipients interference recommends application of the proposed methods in quality control analysis of cited drugs in commercial rotacaps.
\end{abstract}

Key words: Analytical method development, Validation, HPTLC, Mometasone furoate, Formoterol fumarate, DoE.

\section{INTRODUCTION}

Disease of chronic obstructive airway is predicated to become the third cause of mortality by 2030 according to the World Health Organization. ${ }^{1}$ The inflammation in COPD and asthma can be controlled in more efficient manner by straight way delivering the drug in the airways and lungs which will minimize the dose and its side effects. ${ }^{2}$ Such drugs can be delivered through pulmonary route for its significant effect. Nebulizers, pressurized metered-dose inhaler (pMDI) and dry powder inhalers (DPIs) are widely used device for the distribution of active drug moiety as aerosols. To deliver powder medication, DPIs are commonly used as it required least patient synchronization between breathing and actuation. ${ }^{3}$ Though DPI provide good stability to drug formulation than liquid formulation but it is associated with complication of manufacturing powders with the appropriate characteristics to give ease of aerosolization and alveolar delivery. Evocort ${ }^{\circledR}$ inhaler is a combination medication of corticosteroids mometasone furoate and bronchodilators formoterol fumarate for treating asthma, a reversible obstructive airways disease. These DPIs are formulated as low-drug dose products
Submission Date: 01-01-2021; Revision Date: 25-02-2021; Accepted Date: 12-04-2021

DOI: 10.5530/ijper.55.2s.130 Correspondence: Dr. Aarti S Zanwar Associate Professor, Department of Pharmacy, Sumandeep Vidyapeeth Deemed to be, University, Piparia, Waghodia,

Vadodara-391760, Gujarat, INDIA.

Phone no: +919724628289 Email id: aarti.zanwar@gmail. com

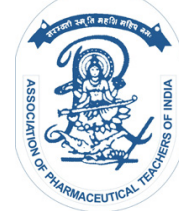

www.ijper.org 


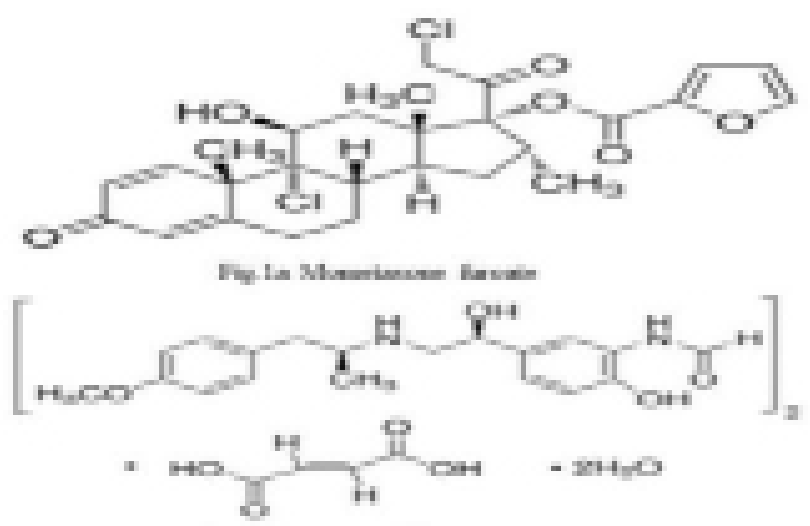

Figure 1: Chemical Structure of (a) Mometasone furoate and (b) Formoterol fumarate.

with microgram doses and it produces the additive effect for improving the symptoms, lung functions and reduces exacerbation in patient. ${ }^{4,5}$

Mometasone furoate (MMF) chemically is $9 \alpha, 21$ dichloro-11 $\beta$-hydroxy-16 $\alpha$ methylpregna-1,4-diene3,20-dione 17-(2-furoate) (Figure 1). Solubility of MMF is less in alcohol, unsolvable in water and freely dissolved in acetone and dichloromethane. Formoterol fumarate (FRF) chemically is $\left(\mathrm{R}^{*}, \mathrm{R}^{*}\right)-\mathrm{N}-[2-$ Hydroxy5-[1-hydroxy-2-[[2-(4-methoxyphenyl) -1-methylethyl] amino] ethyl] phenyl] formamide fumarate, dihydrate (Figure 1). Its show very low ability to dissolved in water and iso propanol; practically insoluble in acetonitrile; soluble in methyl alcohol. ${ }^{6-10}$

Extensive literature survey discloses that estimation of mometasone furoate single or in admixture with other drugs using chromatographic method (HPLC, HPTLC, GC and supercritical fluid) and UV spectrophotometry. ${ }^{10-21}$ The estimation of FRF alone and in combination (mixture) with other active drug moiety including HPLC, GC and UV spectrophotometry has stated in published paper. ${ }^{22-36}$

The advancement of planar chromatography i.e., HPTLC has been arose as a chief tool in drug investigation and simplest of all the chromatographic techniques. HPTLC, a separation technique is flexible and rapid for quantitatively evaluation of extensive range of samples. The experimental design approach is the technique of simultaneous examination of the influence of different factors on robustness of the method using a certain plan (matrix) of experiments. ${ }^{37,38}$ So, there was a need to develop the new alternative HPTLC method which is more sensitive than, the reported method ${ }^{39}$ and the robustness parameters are evaluated with the help of DOE approach.

\section{MATERIALS AND METHODS}

\section{Materials}

Mometasone furoate (MMF) pure drug and Formoterol fumarate (FRF) was supplied as gratis sample from Sun Pharmaceutical Industries Ltd. Evocort ${ }^{\circledR}$ manufactured by Cipla Ltd. was purchased from local market. Toluene, methyl alcohol, ethyl alcohol, N, N-Diethylethanamine, orthophosphoric acid, triethylamine, ethanoic acid, methanoic acid of AR grade was procured from Loba Chemie Pvt. Ltd. Mumbai, India.

\section{Instrument}

The HPTLC system (Camag, Mutenz, Switzerland) consisting semi-automatic spotting device, Linomat V, an HPTLC syringe (100 $\mu$ l capacity) a glass twin-trough TLC chamber $(20 \times 10 \mathrm{~cm})$ for the development of the TLC plate and a TLC scanner- Camag 3 with winCATS (V 1.4.7) software for the interpretation and evaluation, was used for thin layer chromatographic studies. UV cabinet: $254 \mathrm{~nm}$ and $366 \mathrm{~nm}$ for detection of spots and Pre-coated TLC plate: Silica gel $60 \mathrm{~F}_{254}$ Aluminium backed layer $(200 \mu \mathrm{m})$ as stationary phase was used in the study.

\section{Procedure for references stock and sample solution}

Reference stock solution containing $1000 \mu \mathrm{g} / \mathrm{ml}$ of FRF and $6660 \mu \mathrm{g} / \mathrm{ml}$ of MMF concentration was prepared by weighing $10 \mathrm{mg}$ and $66.6 \mathrm{mg}$ of reference FRF and MMF, in separate $10 \mathrm{ml}$ standard flask using solvent as methyl alcohol. Working standard of concentration 40 and $1332 \mu \mathrm{g} / \mathrm{ml}$ of FRF and MMF was prepared by mixing $1 \mathrm{ml}$ of FRF and $5 \mathrm{ml}$ of MMF stock solution in $25 \mathrm{ml}$ standard flask.

\section{Sample solution}

The powder content of forty rotacaps were emptied and accurately weighed. Appropriate quantity of the fine powder $(807.6 \mathrm{mg}$ ) corresponding to $0.2 \mathrm{mg}$ of FRF and $6.66 \mathrm{mg}$ of MMF was placed to a $10 \mathrm{ml}$ standard flask holding $5 \mathrm{ml}$ of methyl alcohol. The solution was sonicated and methyl alcohol was added up to $10 \mathrm{ml}$. Contents were filtered through $0.45 \mu \mathrm{m}$ membrane filter and the conc. of 20 and $666 \mu \mathrm{g} / \mathrm{ml}$ of FRF and MMF, respectively was obtained.

\section{Marketed formulation quantitative analysis}

FRF $(20 \mu \mathrm{g} / \mathrm{ml})$ and MMF $(666 \mu \mathrm{g} / \mathrm{ml})$ was extracted from Evocort ${ }^{\circledR}$. Twelve microliters of the above sample solution were applied on the TLC plate and examined by developed technique. Based on analyte's peak area, 
percentage assay of FRF and MMF in the formulation was calculated.

\section{Chromatographic Condition}

The HPTLC chromatographic condition was optimised using aluminium sheets previously coated with silica gel $60 \mathrm{~F}_{254}$ and toluene: methyl alcohol: methanoic acid (12.5:4:0.3 v/v/v) as mobile phase. The mobile phase was allowed to saturate the chamber for $20 \mathrm{~min}$. The band width of $6 \mathrm{~mm}$ spotted plates was kept in it and mobile phase was allowed to travel up to $80 \mathrm{~mm}$ and then dried for $5 \mathrm{~min}$ in oven at $110^{\circ} \mathrm{C}$. Thereafter, $220 \mathrm{~nm}$ of scanning wavelength was chosen, deuterium lamp was used as radiation source with $40 \mathrm{~mm} / \mathrm{s}$ of scanning speed and $6 \times 0.45 \mathrm{~mm}$ dimension of silt. Developed plate was placed in a scanner which help in the estimation of analyte quantitatively by measuring the intensity of diffused reflected light corresponding to peak area and $\mathrm{R}_{f}$ values.

\section{Validation of Chromatographic Method ${ }^{40}$}

Specificity of the method was assessed by relating the peak purity of chromatographic peaks and analyzing the $\mathrm{R}_{f}$ value of analyte in the pharmaceutical dosage form with the standard drug solution. The band of FRF and MMF in Evocort ${ }^{\circledR}$ were compared with $\mathrm{R}_{f}$ values and densito-spectra of band of reference drugs.

Linearity between the quantity of analyte and their peak area was assessed by applying different volumes, i.e., 3, 6, 9, 12, 15 and $18 \mu \mathrm{l}$ (FRF: 120-720 ng/band; MMF: 3996-23976 ng/band) of reference solution (FRF: $40 \mu \mathrm{g} / \mathrm{ml}$ and MMF:1332 $\mu \mathrm{g} / \mathrm{ml}$ ). The developed plate was analysed and chromatograms were computed. Calibration curve using peak area vs ng/band were sketch for linear representation and slope, intercept and coefficient of determination values were calculated by least square method. The limit of detection and limit of quantification of FRF and MMF were calculated using the equation as mention in ICH guideline i.e., $3 \alpha / \mathrm{S}$ and $10 \alpha / \mathrm{S}$ equation. Repeatability, intraday and interday precision was performed to assess the level of agreement in the value obtained by proposed method. Repeatability study was performed at concentration 240 and $7992 \mathrm{ng} /$ band of FRF and MMF, respectively after assessing the solution six times in same chromatographic condition, $\%$ RSD was computed. At same day and different day precision studies expressed in term of $\%$ RSD were performed by analysing three aliquots of $240,480,720$ (ng/band) and 7992, 15984, 23976 (ng/band) of FRF and MMF, respectively in triplicate. The closeness to true value was assessed at 50,100,150\% level and analysis were performed thrice times for calculating $\%$ recovery.
Robustness of the method was evaluated on the basis of slight variation in the mobile phase composition of, amount of methyl alcohol in mobile phase, amount of mobile phase, time required to saturate the chamber, development distance, time period required from chromatography to scanning etc by applying factorial design [FFD], ${ }^{38,41}$ five factors i.e., half fractional design $\left(2^{5-1}\right)$. In the current analysis, five factors were nominated depending on the factor criticality spotted during trial runs and knowledge from the literature and previous studies that are volume of the polar solvent i.e., methyl alcohol in composition of mobile phase (A) volume of mobile phase (B), development distance (C), chamber saturation time (D) time from chromatography to scanning (E). Four critical quality attributes were (CQA) FRF Rf, FRF peak area, MMF Rf, MMF peak area. To examine the deviation quantitatively of the measured response i.e., $\mathrm{R} f$ and peak area of FRF and MMF, the range of factors inspected were intentionally altered from the finalised chromatographic condition. High and low level were set for the mentioned factor by doing the deliberate variation (Table 1). Randomized order was followed to minimize the bias effect of uncontrolled factors of selected variable in experimental domain to perform all trails. After completion of trials robustness of the method was investigated as per the experimental domain by computing the responses such as retention factor and peak area of FRF and MMF.

\section{RESULTS AND DISCUSSION}

The migration pattern of the MMF and FRF was studied using single solvents such as methyl alcohol, ethylacetate, chloroform, toluene, acetonitrile, isopropyl alcohol etc on the TLC plates. It was observed that FRF spot migrates with methyl alcohol, isopropyl alcohol only, however, MMF spot migrates with both semi polar and polar solvent. Depending on the migration pattern of FRF and MMF, various solvent system composed of different ratio such as chloroform: ethylacetate: methyl alcohol $(6: 3: 1 \mathrm{v} / \mathrm{v} / \mathrm{v})$, toluene: isopropanol: methyl

Table 1: Experimental factors and levels used in fractional factorial design.

\begin{tabular}{|l|c|c|}
\hline \multicolumn{1}{|c|}{ Factor } & High Level & Low level \\
\hline $\begin{array}{l}\text { Amount of methyl alcohol in mobile } \\
\text { phase, } \mathrm{ml}[\mathrm{A}]\end{array}$ & 4.2 & 3.8 \\
\hline Volume of mobile phase, $\mathrm{ml}(\mathrm{B})$ & 17.62 & 14.98 \\
\hline Development distance, mm (C) & 85 & 75 \\
\hline Chamber saturation time, minute (D) & 25 & 15 \\
\hline $\begin{array}{l}\text { Time from chromatography to } \\
\text { scanning, minute (E) }\end{array}$ & 25 & 15 \\
\hline
\end{tabular}




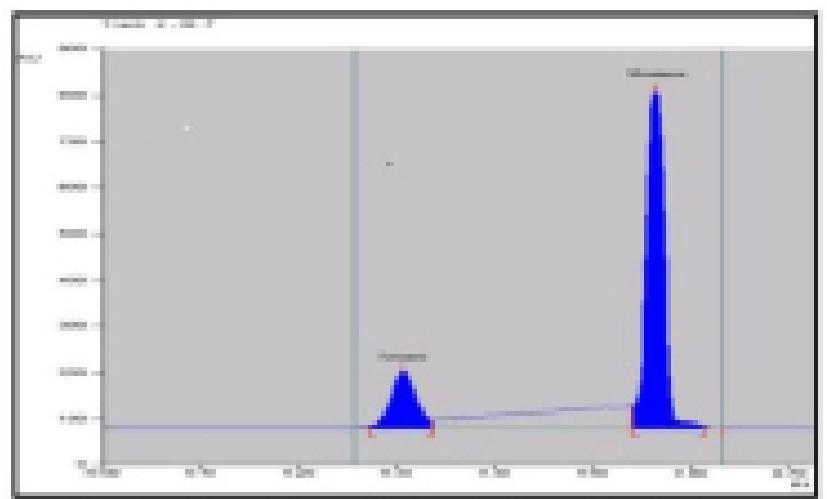

Figure 2: HPTLC chromatogram of formoterol fumarate (240 ng/band) and mometasone furoate (7992 ng/band).

alcohol $(6: 2: 2 \mathrm{v} / \mathrm{v} / \mathrm{v})$; toluene: methyl alcohol $(8: 2 \mathrm{v} / \mathrm{v})$ were tried, but MMF spot migrated near solvent front. Polarity difference of FRF (polar) and MMF (non-polar) is high. So, simultaneous estimation of both the drug with good $\mathrm{R}_{f}$ values was a challenging task. After serval trials mobile phase consisting of toluene: methyl alcohol $(12.5: 4 \mathrm{v} / \mathrm{v})$ showed acceptable $\mathrm{R}_{f}$ values but the peak symmetry of FRF was not within acceptable range. To correct the peak symmetry of FRF which is weakly acidic drug, methanoic acid, ethanoic acid, triethylamine was tried. Methanoic acid was selected as it improves peak symmetry. So, mobile phase system consisting of toluene: methyl alcohol: methanoic acid (12.5:4:0.3 $\mathrm{v} / \mathrm{v} / \mathrm{v}$ ) was selected. A solvent system that gave dense compact spots, good separation between FRF and MMF and also separation from solvent front and application position was selected as shown in Figure 2 with reproducible $\mathrm{R}_{f}$ values $0.316 \pm 0.021$ and $0.569 \pm 0.029$ for FRF and MMF, respectively.

The band obtained of FRF and MMF after applying optimised chromatographic condition in the analysis of Evocort $^{\circledR}$ completely match with $\mathrm{R}_{f}$ values and densito-spectra of band of reference drugs. The obtained value of peak purity was near the value of 0.999 defining the specificity of analyse. The concentration of FRF and MMF was found to be directly proportional to its response i.e., peak area in range of 120-720 ng/band and 3996-23976 ng/band, respectively. After applying regression analysis, the calculated value of intercept, slope and correlation coefficient are shown in Table 2 are satisfactory for the method to be linear. The overlay spectra are shown in Figure 3. The values of LOD and LOQ were found to be 21.94, 1160.73 $\mathrm{ng} / \mathrm{band}$ and 66.49, $3517.37 \mathrm{ng} / \mathrm{band}$ for FRF and MMF, respectively representing the determination ability of the method. Results of precision studies was between $0.77-1.274$ stated in \% RSD indicates good repeatability

\begin{tabular}{|c|c|c|}
\hline Parameters & FRF & MMF \\
\hline Linearity range (ng/band) & $120-720$ & $3996-23976$ \\
\hline Correlation coefficient & 0.999 & 0.999 \\
\hline Regression Equation & $\begin{array}{c}y=5.715 x+ \\
77.06\end{array}$ & $\begin{aligned} y= & 0.251 x+ \\
& 7187\end{aligned}$ \\
\hline LOD (ng/band) & 21.943 & 1160.734 \\
\hline LOQ (ng/band) & 66.495 & 3517.375 \\
\hline $\begin{array}{c}\text { Precision (\%RSD) } \\
\text { Intra-day }(n=3) \\
\text { Inter-day }(n=3) \\
\text { Repeatability }(n=6)\end{array}$ & $\begin{array}{l}0.974 \\
1.274 \\
0.820\end{array}$ & $\begin{array}{l}1.050 \\
1.185 \\
0.770\end{array}$ \\
\hline \multicolumn{3}{|l|}{$\begin{array}{l}\text { Accuracy (\% Recovery } \\
\text { studies, } n=3 \text { ) }\end{array}$} \\
\hline 50 & $\begin{array}{c}99.762 \pm \\
1.541\end{array}$ & $\begin{array}{c}100.749 \pm \\
1.598\end{array}$ \\
\hline 100 & $\begin{array}{c}100.972 \pm \\
0.716\end{array}$ & $\begin{array}{c}100.836 \pm \\
1.585\end{array}$ \\
\hline 150 & $\begin{array}{c}99.235 \pm \\
1.210\end{array}$ & $\begin{array}{c}101.122 \pm \\
1.260\end{array}$ \\
\hline
\end{tabular}

$*_{\mathrm{n}}=$ number of determinations, \% RSD (Percentage relative standard deviation)

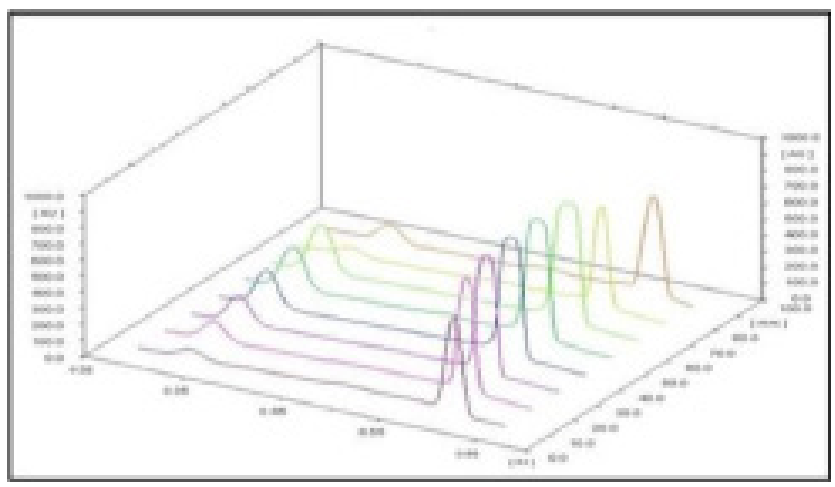

Figure 3: Overlain 3D chromatogram of FRF and MMF.

and low inter-day variability. Recovery studies ranged from $99-101 \%$ are shown in (Table 2) for both the drugs indicating the closeness toward expected value.

Fractional Factorial Design DoE was applied to perform robustness study (Table 3). $2^{5-1}$ with factors being varied over two levels: fractional and maximum. Four critical quality attributes were (CQA) FRF Rf, FRF Peak area (PA), MMF Rf, MMF Peak area (PA) and their obtained value from pareto charts, 3 -D response surface plot and perturbation plot are shown in Figure 4a-4f. The desirability value obtained for all CQAs from Pareto charts, 3-D response surface plot, perturbation plot, suggest organic modifier was contributing more in altering response of $\mathrm{R}_{f}$ of FRF and MMF (Figure 4a-4c). ANOVA equation also shows the same. Mobile phase 


\begin{tabular}{|c|c|c|c|c|c|c|c|c|}
\hline Factor 1 & Factor 2 & Factor 3 & Factor 4 & Factor 5 & Response 1 & Response 2 & Response 3 & Response 4 \\
\hline $\begin{array}{c}\text { A: } \\
\text { M/P } \\
\text { Organic } \\
\text { Modifier }\end{array}$ & $\begin{array}{c}\text { B: } \\
\text { M/P } \\
\text { Volume }\end{array}$ & $\begin{array}{c}\text { C: } \\
\text { Develop- } \\
\text { ment } \\
\text { Distance }\end{array}$ & $\begin{array}{c}\text { D: } \\
\text { Chamber } \\
\text { Saturation } \\
\text { Time }\end{array}$ & $\begin{array}{c}\text { E: } \\
\text { Time from } \\
\text { Chroma- } \\
\text { tography } \\
\text { to } \\
\text { Scanning }\end{array}$ & FRF Rf & FRF PA & MMF Rf & MMF PA \\
\hline 3.8 & 14.98 & 85 & 25 & 25 & 0.309 & 1459.43 & 0.542 & 9138.67 \\
\hline 3.8 & 17.62 & 75 & 15 & 15 & 0.309 & 1498.43 & 0.548 & 9279.9 \\
\hline 4.2 & 14.98 & 75 & 15 & 15 & 0.328 & 1476.67 & 0.584 & 9025.78 \\
\hline 4.2 & 14.98 & 75 & 25 & 25 & 0.326 & 1498.8 & 0.585 & 9212.62 \\
\hline 4.2 & 14.98 & 85 & 15 & 25 & 0.328 & 1498.43 & 0.582 & 9046.57 \\
\hline 3.8 & 14.98 & 75 & 15 & 25 & 0.299 & 1456.7 & 0.541 & 9138.56 \\
\hline 3.8 & 14.98 & 85 & 15 & 15 & 0.298 & 1459.44 & 0.542 & 9025.78 \\
\hline 3.8 & 17.62 & 75 & 25 & 25 & 0.309 & 1476.72 & 0.548 & 9267.57 \\
\hline 3.8 & 14.98 & 75 & 25 & 15 & 0.308 & 1459.44 & 0.541 & 9089.68 \\
\hline 4.2 & 17.62 & 85 & 15 & 15 & 0.329 & 1456.72 & 0.589 & 9189.62 \\
\hline 4.2 & 17.62 & 75 & 15 & 25 & 0.329 & 1476.76 & 0.589 & 9138.67 \\
\hline 4.2 & 14.98 & 85 & 25 & 15 & 0.326 & 1459.43 & 0.582 & 9138.67 \\
\hline 3.8 & 17.62 & 85 & 15 & 25 & 0.311 & 1459.43 & 0.543 & 9142.64 \\
\hline 4.2 & 17.62 & 85 & 25 & 25 & 0.329 & 1459.43 & 0.589 & 9138.67 \\
\hline 4.2 & 17.62 & 75 & 25 & 15 & 0.331 & 1498.69 & 0.588 & 9286.54 \\
\hline 3.8 & 17.62 & 85 & 25 & 15 & 0.311 & 1456.72 & 0.544 & 9138.67 \\
\hline
\end{tabular}

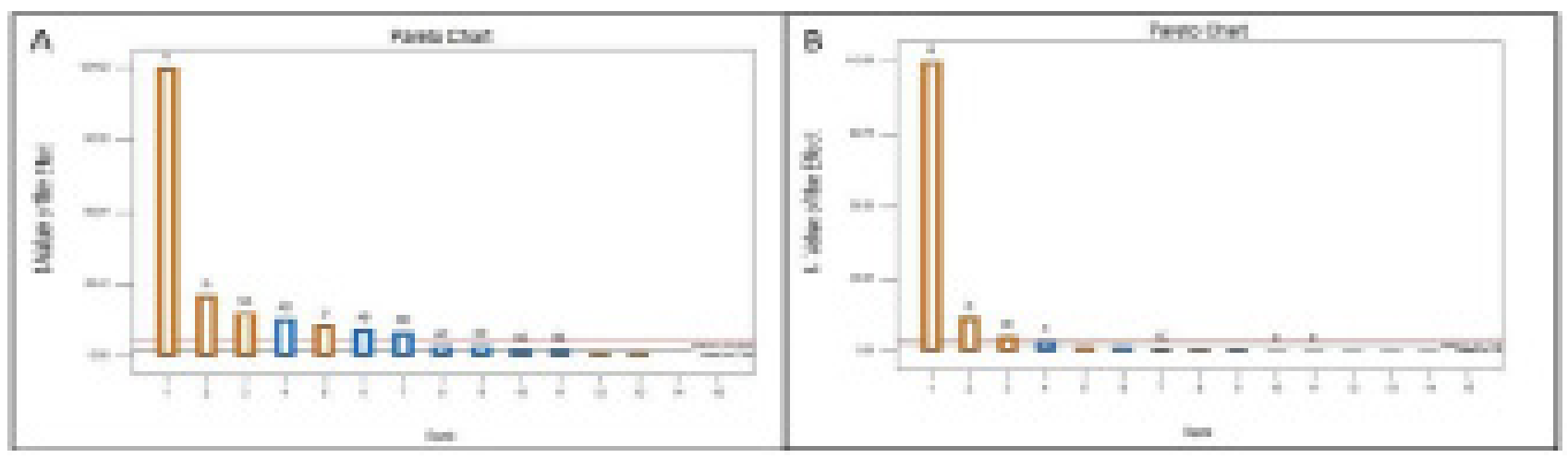

Figure 4a: Pareto chart FRF (A) and MMF (B) showing the effect of factors and interaction on the $R_{f}$ values.

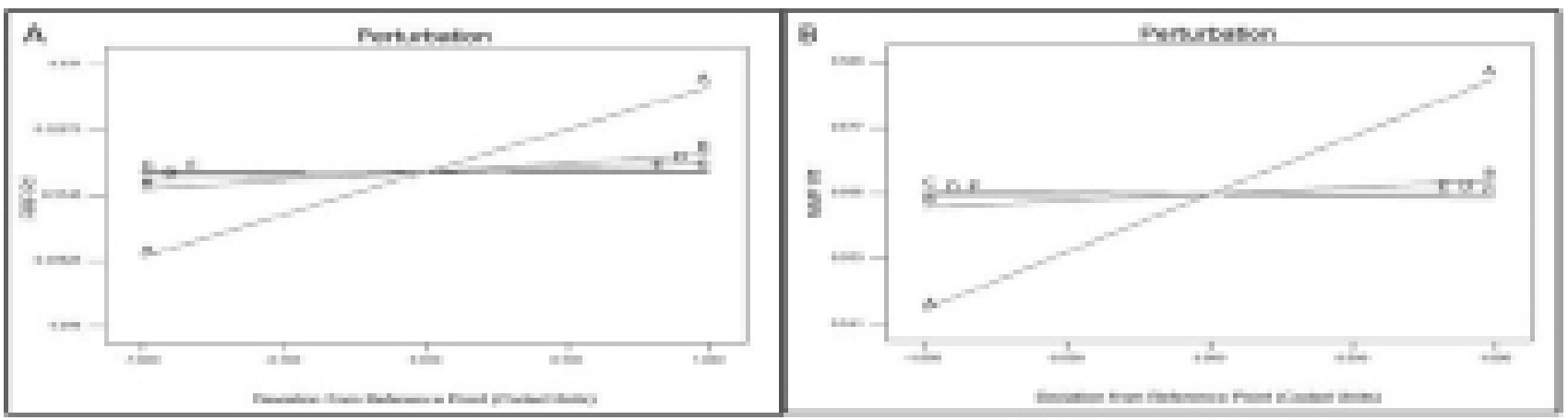

Figure 4b: Perturbation plot of $\operatorname{RrF}(A)$ and $M M F(B)$ showing effect of factors on $R_{f}$ values. 


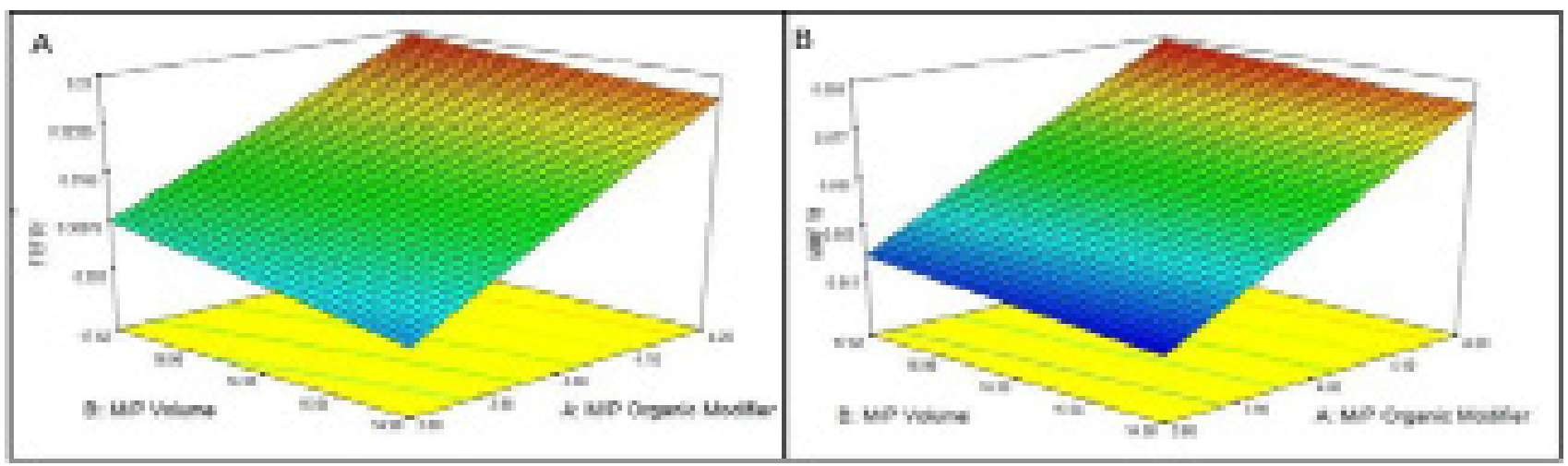

Figure 4c: Three- dimensional response surface plot of $\mathrm{FRF}(A)$ and $M M F(B)$ displaying the effect of factors on $R_{f}$ values.

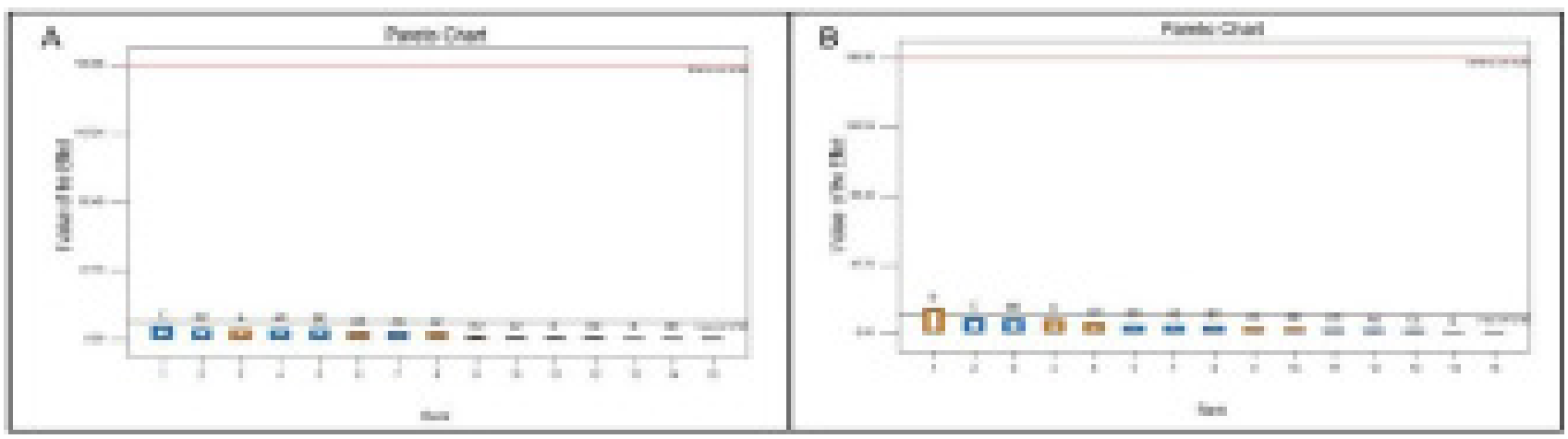

Figure 4d: Pareto chart of $\operatorname{RrF}(A)$ and $M M F(B)$ showing the effect of factors and interaction on the peak area values.
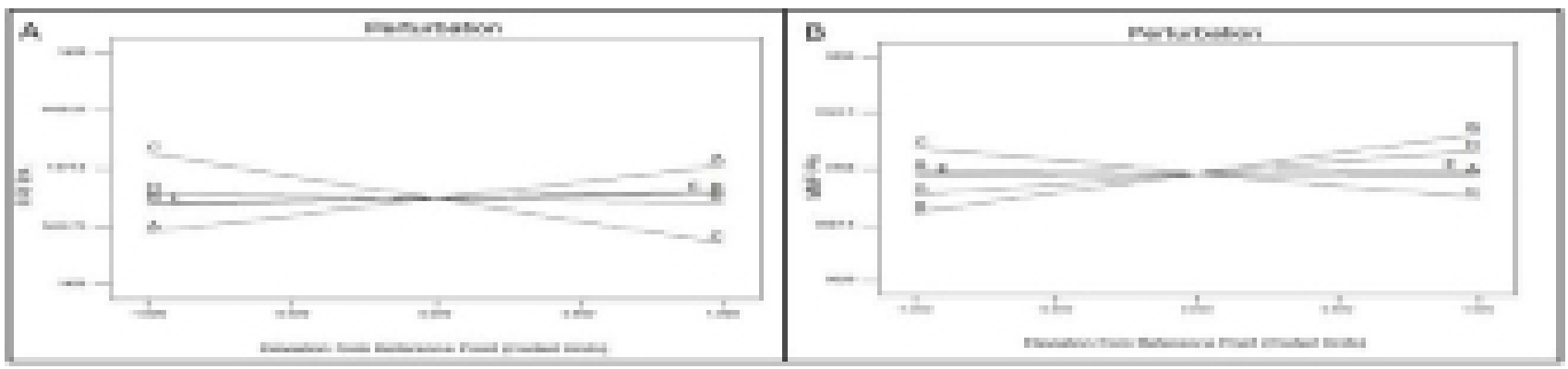

Figure 4e: Perturbation plot showing effect of $\operatorname{FRF}(A)$ and $M M F(B)$ factors on peak area values.
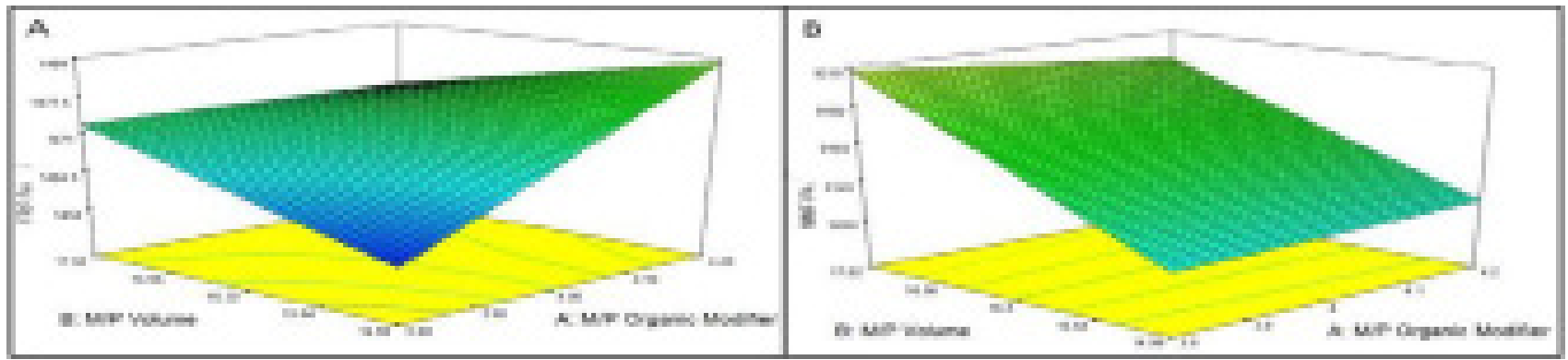

Figure 4f: Three- dimensional response surface plot of $F R F(A)$ and $M M F(B)$ displaying the effect of factors on peak area values.

organic modifier should be controlled. Limit has to be set and strictly controlled for the $\mathrm{M} / \mathrm{P}$ organic modifier for $\mathrm{R}_{f}$ of FRF and MMF. Study of peak area of FRF and MMF showed that the method was robust against the evaluated five factors (Figure 4d-4f). Perturbation plots specified that little difference in volume of mobile phase had effects which is vital but unable to-show any noteworthy outcome on retention factor except MMF as shown in Figure 4b. Observation can be made from the threedimensional response surface plots, an increase in concentration of methyl alcohol in the mobile phase result into the slight upward shift of $\mathrm{R}_{f}$ value of FRF and MMF as shown in Figure 4(c). quations obtained from the model as: 


\begin{tabular}{|c|c|c|c|c|}
\hline \multicolumn{4}{|c|}{ Table 4: Results of Formulation Analysis. } \\
\hline \multirow{2}{*}{ Drugs } & Amount ( $\boldsymbol{\mu g}$ /rotacaps) & \multirow{2}{*}{$\begin{array}{c}\text { \% Drug } \\
\text { found }\end{array}$} & \%RSD \\
\cline { 2 - 3 } & Labeled & Found $^{*}$ & \\
\hline FRF & 6 & $5.93 \pm 0.07$ & $98.94 \pm 1.19$ & 1.21 \\
\hline MMF & 200 & $200.94 \pm 3.62$ & $100.47 \pm 1.81$ & 1. \\
\hline
\end{tabular}

$*$ Mean $\pm S D(n=6)$ values of six determination

$$
\begin{aligned}
& \mathrm{FRF}_{f}=+0.32+0.011 * \mathrm{~A}+2.250 \mathrm{E}-003 * \mathrm{~B}+1.250 \mathrm{E}-004 \\
& * \mathrm{C}+1.125 \mathrm{E}-003 * \mathrm{D}+0.000 * \\
& \text { E -1.000E-003* A * B-3.750E-004 } * \text { A } * \text { C-1.375E-003 } \\
& * \mathrm{~A} * \mathrm{D}-2.500 \mathrm{E}-004 * \mathrm{~A} * \mathrm{E} \\
& -8.750 \mathrm{E}-004 * \mathrm{~B} * \mathrm{D}-2.500 \mathrm{E}-004 * \mathrm{~B} * \mathrm{E}+1.625 \mathrm{E}-003 * \\
& \mathrm{C} * \mathrm{E}-3.750 \mathrm{E}-004 * \mathrm{D} * \mathrm{E} \\
& \text { FRF PA }=+1471.95+6.16 * \mathrm{~A}+0.91 * \mathrm{~B}-8.32 * \mathrm{C}-0.87 * \\
& \mathrm{D}+1.26 * \mathrm{E}-6.13 * \mathrm{~A} * \mathrm{~B} \\
& -1.29 * \mathrm{~A} * \mathrm{C}+1.84 * \mathrm{~A} * \mathrm{D}+3.98 * \mathrm{~A} * \mathrm{E}-6.46 * \mathrm{~B} * \\
& \mathrm{C}+0.90 * \mathrm{~B} * \mathrm{D}-6.04 * \mathrm{~B} * \mathrm{E} \\
& -4.01 * \mathrm{C} * \mathrm{D}+4.29 * \mathrm{C} * \mathrm{E}+1.25 * \mathrm{D} * \mathrm{E} \\
& \text { MMF R } f=+0.56+0.021 * \mathrm{~A}+2.437 \mathrm{E}-003 * \mathrm{~B}-6.875 \mathrm{E}-004 \\
& * \mathrm{C}+6.250 \mathrm{E}-005 * \mathrm{D} \\
& +6.250 \mathrm{E}-005 * \mathrm{E}+1.875 \mathrm{E}-004 * \mathrm{~A} * \mathrm{C}+1.062 \mathrm{E}-003 * \\
& \mathrm{D} * \mathrm{E} \\
& \text { MMF PA }=+9149.91-2.77 * \mathrm{~A}+47.87 * \mathrm{~B}-30.00 * \mathrm{C} \\
& +26.47 * \mathrm{D}+3.08 * \mathrm{E}-6.64 * \mathrm{~A} * \\
& \mathrm{~B}+11.24 * \mathrm{~A} * \mathrm{C}+20.51 * \mathrm{~A} * \mathrm{D}-16.09 * \mathrm{~A} * \mathrm{E}-15.38 * \\
& \mathrm{~B} * \mathrm{C}-16.40 * \mathrm{~B} * \mathrm{D}-28.98 * \mathrm{~B} * \\
& \mathrm{E}-7.71 * \mathrm{C} * \mathrm{D}-6.36 * \mathrm{C} * \mathrm{E}+9.91 * \mathrm{D} * \mathrm{E}
\end{aligned}
$$

\section{Analysis of formulation}

The obtained ( $\%$ assay) were in the range $98-100$ (Table 4). This result suggests that, projected HPTLC investigation was successfully used to find the quantitative amount of FRF and MMF in rotacaps formulation (6 $\mu \mathrm{g}$ of FRF and $200 \mu \mathrm{g}$ of MMF per rotacaps).

\section{CONCLUSION}

The suggested method provide assurance about the sensitivity, effortlessness and specificity for quantitation of the studied drugs in their authentic powders. The Fractional factorial design proposed that the content of methyl alcohol can influence the $\mathrm{R}_{f}$ value of $\mathrm{MMF}$ more in comparison to FRF, so it has to be control efficiently for the reproducibility of results. The compatibility of linearity ranges with ratio in their combined rotacaps and also nonappearance of excipients interference recommends application of the proposed methods in quality control analysis of cited drugs in commercial rotacaps.

\section{ACKNOWLEDGEMENT}

The authors are thankful to Department of Pharmacy, Sumandeep Vidyapeeth Deemed to be University, Vadodara and Institute of Pharmacy Education and Research, Wardha for providing the facilities for this research work.

\section{CONFLICT OF INTEREST}

The authors declare no conflict of interest.

\section{ABBREVIATIONS}

FRF: Formoterol Fumarate; MMF: Mometasone furoate; $\mathbf{R}_{f:}$ Retardation factor; HPTLC: High performance thin layer chromatography; RSD: Relative Standard Deviation; SD: Standard deviation; API: Active pharmaceutical ingredient.

\section{REFERENCES}

1. Rabe KF, Hurd S, Anzueto A, Barnes PJ, Buist SA, Calverley P, et al. Global strategy for the diagnosis, management and prevention of chronic obstructive pulmonary disease: GOLD executive summary. Am J Respir Crit Care Med. 2007;176(6):532-55.

2. Ibrahim M, Verma R, Garcia-Contreras L. Inhalation drug delivery devices: Technology update. Medical Devices (Auckland, NZ). 2015;8:131.

3. Sanchis J, Corrigan C, Levy ML, Viejo JL. Inhaler devices-from theory to practice. Respiratory Medicine. 2013;107(4):495-502.

4. Labiris NR, Dolovich MB. Pulmonary drug delivery. Part II: The role of inhalant delivery devices and drug formulations in therapeutic effectiveness of aerosolized medications. Br J Clin Pharmacol. 2000;56(6):600-12.

5. Montusch P. Pharmacological treatment of chronic obstructive pulmonary disease. Int J Chron Obstruct Pulmon Dis. 2006;1(4):409-23.

6. The Merck Index. An encyclopedia of chemicals, drug and biological, $15^{\text {th }}$ edition. White House Station, NJ, Merck and Co., Inc; 2001;779, 1146-47, 1161.

7. Martindale. The complete drug reference, $38^{\text {th }}$ edition, volume I, London, UK, Pharmaceutical press (an imprint of RPS publishing); 2012;327-8, 588-90.

8. Indian Pharmacopoeia, Government of India, Ministry of Health and Family Welfare, Ghaziabad, Indian Pharmacopoeia Commission. 2007;2:1147-8, 1389-90.

9. British Pharmacopoeia, London, UK, Stationary Office, MHRA; 2008;1:1462-64, 1485.

10. USP $31 \mathrm{NF}$, The official compendia of standards, 12601 Twinbrook Parkway, Rockville, MD, The United States Pharmacopeial Convention. 2008;3:2711-13, 2727-9.

11. Malik K, Kumar D, Tomar V, Kaskhedikar S, Soni L. A Simple RP-HPLC Method for the Simultaneous Quantitation of Chlorocresol, Mometasone Furoate and Fusidic Acid in Creams. Der Pharmacia Sinica. 2011;2(6):77-84.

12. Shaikh KA, Patil AT. Stability-Indicating HPLC Method for the Determination of Mometasone Furoate, Oxymetazoline, Phenyl Ethanol and Benzalkonium Chloride in Nasal Spray Solution. J Trace Anal Food Drugs. 2013;1:14-21.

13. Kulkarni A, Nanda RK, Ranjane MN, Ranjane PN. Simultaneous estimation of Nadifloxacin and Mometasone Furoate in topical cream by HPTLC method. Der Pharma Chemica. 2010;2(2):5-30.

14. Sharma N, Rao SS, Vaghela B. Validated Stability-indicating Highperformance Liquid Chromatographic Method for Estimation of Degradation Behaviour of Eberconazole Nitrate and Mometasone Furoate in Cream Formulation. Indian J Pharm Sci. 2013;75(1):76-82. 
15. El-Bagary RI, Elkady EF, Tammam MH, Elmaaty AA. Simultaneous determination of miconazole and hydrocortisone or mometasone using reversed phase liquid chromatography. Eur J Chem. 2012;3(4):421-5.

16. Roy C and Chakrabarty J. Stability-Indicating Validated Novel RP-HPLC Method for Simultaneous Estimation of Methylparaben, Ketoconazole and Mometasone Furoate in Topical Pharmaceutical Dosage Formulation. ISRN Analytical Chemistry. 2013;9.

17. El-Bagary RI, Fouada MA, El-Shaalb MA, Tolba EH. Derivative, derivative of the ratio spectrophotometric and stability-indicating RP-HPLC methods for the determination of mometasone furoate and miconazole nitrate in cream. J Chem Pharm Res. 2013;5(1):368-78.

18. Vanani DR, Desai SD, Patel KG, Shah PA. Application of Ratio Derivative Spectrophotometry for Simultaneous Determination of Mometasone furoate and Salicylic acid in semisolid dosage form. Int $\mathrm{J}$ Anal Bioanal Chem. 2013;3(3):67-71.

19. Zanwar AS, Sen AK, Sen DB, Seth AK. Simultaneous estimation of mometasone furoate and formoterol fumarate by HPLC method in rotacaps. Int J Pharm Pharm Sci. 2019;11(2):12-6.

20. Levin M, Ostanina N, Gumeniuk O, Meleshko R, Tereshchenko O, Nikolaieva Y, et al. Development of simple and fast UV-method for the quantitative determination of mometasone furoate in a large number of metered doses of an aqueous nasal spray of mometasone furoate. Heliyon. 2019;5(11):e02748.

21. Vichare V, Choudhari VP, Reddy MV. Study of Intrinsic Stability of Mometasone Furoate in Presence of Salicylic Acid by HPTLC and Characterization, Cytotoxicity Testing of Major Degradation Product of Mometasone Furoate. Curr Pharm Anal. 2019;15(6):592-603.

22. Campestrini J, Lecaillon JB, Godbillon J. Automated and sensitive method for the determination of formoterol in human plasma by high-performance liquid chromatography and electrochemical detection. J Chromatogr B. 1997;704(1-2): 221-9.

23. Ahmed S, Jayakar B, Aleem MA. Development of reverse phase high performance liquid chromatography method and its validation for estimation of formoterol fumarate rotacaps. Int J Pharm Sci Res. 2011;2(2):319-24.

24. Mohd G, Appala RS, Sultanuddin, Manjunath S. Development and validation of spectrophotometric methods for estimation of formoterol bulk drug and its pharmaceutical dosage forms. Int J Pharm Pharm Sci. 2011;3(3):307-9.

25. Nadarassan DK, Chrystyn H, Clark BJ, Assi KH. Validation of highperformance liquid chromatography assay for quantification of formoterol in urine samples after inhalation using UV detection technique. J Chromatogr $B$ Analyt Technol Biomed Life Sci. 2007;850(1-2):31-7.

26. Akapo SO, Asif M. Validation of a RP-HPLC method for the assay of formoterol and its related substances in formoterol fumarate dehydrate drug substance. J Pharm Biomed Anal. 2003;33(4):935-45.

27. Grahama SJ, Beaulieua N, Loveringa EG. Sensitive high pressure liquid chromatographic assay method for formoterol fumarate. J Liq Chromatogr. 1993;16(7):1497-503.

28. Pai N, Patil SS. Development and validation of RP-HPLC method for estimation of formoterol fumarate and budesonide in pressurized meter dose inhaler form. Der Pharmacia Sinica. 2013;4(4):15-25.
29. Trivedi RK, Chendake DS, Patel MC. A rapid, stability-indicating RP-HPLC method for the simultaneous determination of formoterol fumarate, tiotropium bromide and ciclesonide in a pulmonary drug product. Sci Pharm. 2012;80(3):591-604.

30. Patil AT, Patil SD, Shaikh KA. Sensitive LC method for simultaneous determination of ciclesonide and formoterol fumarate in dry powder inhaler. $J$ Liq Chromatogr Relat Technol. 2011;34(15):1568-77.

31. Pulla RP, Sastry BS, Rajendra PY, Appala RN. RP-HPLC method for simultaneous estimation of formoterol fumarate, tiotropium bromide and ciclesonide in pharmaceutical metered dose inhalers. Asian J Res Chem. 2011;4(4);585-90.

32. Malik K, Kumar D, Tomar V. Kaskhedikar S, Soni L. Simultaneous quantitative determination of formoterol fumarate and fluticasone propionate by validated reversed-phase HPLC method in metered dose inhaler. Der Pharmacia Sinica. 2011;2(6):77-84.

33. Shah BD, Kumar S, Yadav YC, Seth AK, Ghelani TK, Deshmukh GJ. RP-HPLC method developed for estimation of tiotropium bromide and formoterol fumarate in metered dose inhalation dosage form. Asian J Biochem Pharm Res. 2011;1(1):145-56.

34. Prasad AVSS. Simultaneous spectrophotometric determination of formoterol fumarate and budesonide in their combined dosage form. Indian $\mathrm{J}$ Chem Technol. 2006;13:81-3.

35. Zanwar AS, Sen DB, Ruikar DB, Seth AK. Spectroscopic methods for the simultaneous estimation of Mometasone Furoate and Formoterol Fumarate in Rotacaps. Indo American Journal of Pharmaceutical Research. 2014;4(12):5928-33.

36. Erukulla KK, Rengitham SS. Synchronous Estimation of Glycopyrrolate and Formoterol in Bulk and Pharmaceutical Dosage Form by RP-HPLC Method. Int J Pharm Edu Res. 2018;52(4):S47-55.

37. Modi PB, Shah NJ. DoE Approach: A Stability Indicating RP-HPLC Method for Simultaneous Estimation of Methylparaben, Mometasone furoate and Eberconazole nitrate in Topical Formulations. J Appl Pharm Sci. 2014;4(12):20-5.

38. Patel KG, Shah PM, Shah PA, Gandhi TR. Validated high-performance thinlayer chromatographic (HPTLC) method for simultaneous determination of nadifloxacin, mometasone furoate and miconazole nitrate cream using fractional factorial design. J Food Drug Anal. 2016;24(3):610-9.

39. Merey HA, El-Mosallamy SS, Hassan NY, El-Zeany BA. Validated chromatographic methods for the simultaneous determination of Mometasone furoate and Formoterol fumarate dihydrate in a combined dosage form. Bull Fac Pharm Cairo Univ. 2016;54(1):99-106.

40. International Conference on Harmonization. Validation of Analytical Procedures: Methodology, ICH- Q2(R1); 1995.

41. Pandya CP, Rajput SJ. Stress Degradation Studies of Riociguat, Development of Validated Stability Indicating Method, Identification, Isolation and Characterization of Degradation Products by LC-HR-MS/MS and NMR. Indian J Pharm Educ Res. 2019;53(4):S630-41. 
PICTORIAL ABSTRACT

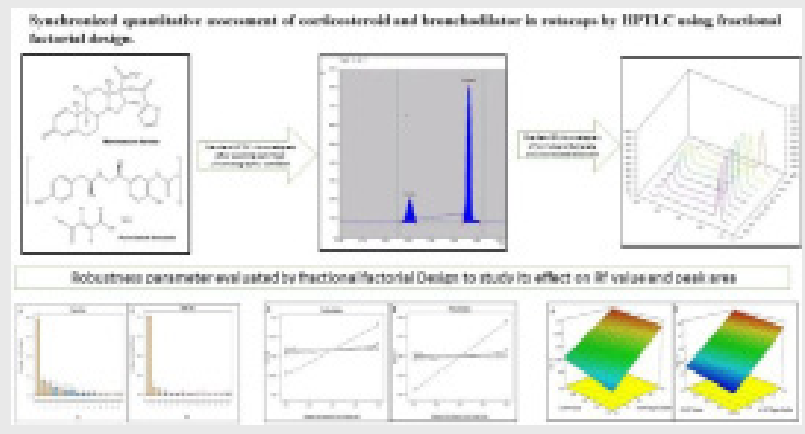

\section{SUMMARY}

- The developed and validated HPTLC method was successfully applied for quantification of formoterol fumarate and mometasone furoate by applying DOE. The mobile phase used for the separation of these two analytes was toluene: methyl alcohol: methanoic acid $(12.5: 4: 0.3 \mathrm{v} / \mathrm{v} / \mathrm{v})$ on stationary phase of silicagel $60 \mathrm{~F}_{254}$.

- $\mathrm{R}_{f}$ values were found to be $0.316 \pm 0.021$ and $0.569 \pm 0.029$ for formoterol fumarate and mometasone furoate, respectively.

- Fractional factorial design was used to examine the effect of multiple robustness parameter efficiently with fewer runs.

- The developed method was successfully validated and therefore can be used in quality control analysis of cited drugs in commercial rotacaps formulation.

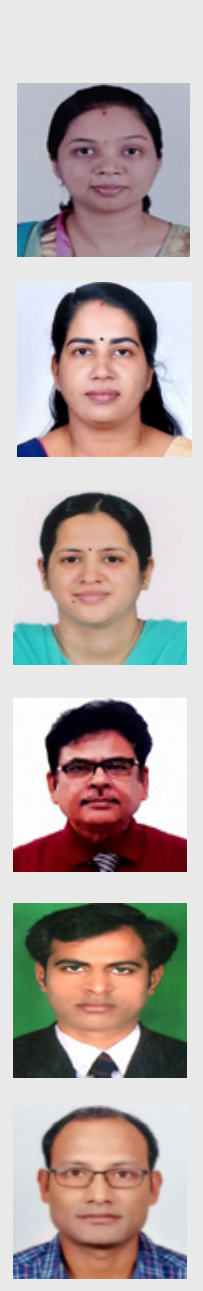

\section{About Authors}

Dr. Aarti S. Zanwar is currently working as Associate Professor in Pharmaceutical Analysis and Quality Assurance, Department of Pharmacy, Sumandeep Vidyapeeth Deemed to be University, Piparia, Waghodia, Vadodara. Her area of interests is development and validation of different analytical methods using HPLC, HPTLC, UV spectrophotometer etc.

Dr. Dhanya B Sen Currently working as Associate Professor in Pharmaceutical Analysis and Quality Assurance, Department of Pharmacy, Sumandeep Vidyapeeth Deemed to be University, Piparia, Waghodia, Vadodara.

Charu P Pandya, is an Assistant Professor at Parul Institute of Pharmacy, Parul University, Vadodara. She has done Ph.D from Faculty of Pharmacy, The Maharaja Sayajirao University of Baroda. Her area of interests is synthesis of heterocyclic compounds, method development, imupurity profiling of drugs, quality by design method development.

Dr. Avinash K, Seth is Professor and Principal in Department of Pharmacy, Sumandeep Vidyapeeth Deemed to be University, Vadodara, India.

Dr. Rajesh A, Maheshwari is Professor in Department of Pharmacy, Sumandeep Vidyapeeth Deemed to be University, Vadodara, India. He has also been honored with Member of National Academy of Medical Sciences, India (MAMS) in 2017 for his contribution towards the Medical Research.

Dr. Ashim K. Sen is currently working as Professor in Pharmaceutical Analysis and Quality Assurance, Department of Pharmacy, Sumandeep Vidyapeeth Deemed to be University, Piparia, Waghodia, Vadodara-391760, Gujarat, India

Cite this article: Zanwar AS, Sen DB, Pandya CP, Seth AK, Maheshwari R, Sen AK. Synchronized Quantitative Assessment of Corticosteroid and Bronchodilator in Rotacaps by HPTLC using Fractional Factorial Design. Indian J of Pharmaceutical Education and Research. 2021;55(2s):s580-s588. 